\title{
Effect of N-P-K fertilization on yield and tiller density of creeping bluestem
}

\author{
ROB S. KALMBACHER, FRANK G. MARTIN, AND JACK E. RECHCIGL
}

\begin{abstract}
Authors are agronomist, Ona Agricultural Research and Education Center (AREC), Ona, Fla. 33865; professor Department of Statistics, University of Florida, Gainesville 32611; and associate soil scientist, Ona AREC.
\end{abstract}

\begin{abstract}
Forage quality and quantity from palatable grasses, like creeping bluestem [Schizachyrium scoparium (Michx.) Nash var. polycladus (Schriber \& Ball) Bruner (Syn S. stoloniferum Nash.)], are limited, especially in winter when cows graze Florida range. We anticipated that $\mathrm{N}$ fertilizer $\left(0,40,60,120 \mathrm{~kg} \mathrm{ha}^{-1}\right), P\left(0,25 \mathrm{~kg} \mathrm{ha}^{-1}\right)$ and $K\left(0,100 \mathrm{~kg} \mathrm{ha}^{-1}\right)$ would increase bluestem yield, tiller density, and forage quality. Within sample dates yield and tiller density increased linearly with $\mathbf{N}$ rate. For example 31 days after fertilization, intercepts for equations predicting yield were $319 \mathrm{~kg} \mathrm{ha}^{-1}$ and $124 \mathrm{~m}^{-2}$ with coefficients of 1.2 and 0.29 , respectively, where the independent variable is $\mathbf{N}$ rate. Over sample dates yield responses to $\mathbf{N}$ rate were quadratic and tiller densities were cubic. Reproductive tiller density was increased by $\mathbf{N}$ fertilization (1989 tiller density, no. $\left.\mathrm{m}^{-2},=30+0.29 \mathrm{~N}\right)$. Neither yield nor tiller density was affected by $P$ fertilizer, but $K$ fertilizer increased reproductive tiller density, hence fall yield. After 3 years of fertilization, $N$ had negative quadratic and negative linear effects on yield and tiller density, respectively. Tissue $\mathbf{N}$ concentration in the fall was reduced with $\mathbf{N}$ fertilization because of increases in reproductive growth (1988 calendar 145 days postfertilization, $\mathrm{g} \mathrm{kg}^{-1}=5.7-$ $0.041 \mathrm{~N}+0.00031 \mathrm{~N}^{2}$ ). Fertilization of creeping bluestem is not a recommended practice when bluestem is to be grazed in fall and winter.
\end{abstract}

Key Words: sub-tropical range, N,P,K fertilization, soil N, Schizachyrium scoparium

Forage yield of some Florida range has increased as a result of roller chopping and deferment of grazing for a growing season after treatment (Yarlett 1965). The increase is attributed to a decrease in saw-palmetto (Serenoa repens [Bartr.] Small) and pineland threeawn (Aristida stricta Michx.) cover with increases in grasses such as creeping bluestem (Schizachyrium scoparium [Michx.] Nash var. polycladus [Schribner \& Ball] Bruner [Syn $S$. stoloniferum Nash.]) (Yarlett and Roush 1970). Although creeping bluestem, which is a strongly rhizomatous variety of $S$. scoparium, is capable of relatively high yield in small plots (Kalmbacher et al. 1981 ), creeping bluestem yield may be only 300 to $400 \mathrm{~kg} \mathrm{ha}^{-1}$ on range in good condition (Kalmbacher et al. 1984). Creeping bluestem is palatable and forms about $40 \%$ of the dry matter in cattle diets year-round (Kalmbacher et al. 1984), but digestibility is at best only sufficient for cow maintenance (Long et al. 1986a). Burning (Kalmbacher et al. 1985) and time and frequency of grazing (Kalmbacher et al. 1986, Long et al. 1986b) resulted in shortlived (4 to 6 months) improvements in protein and digestibility.

Fertilization (usually with N, P, and K-singly or in combinations) in the Northern Great Plains has resulted in improved species composition, increased forage production, and protein (Goetz 1975), as well as increased water-use efficiency and palatability

\footnotetext{
University of Florida Journal Series R-02142.
}

Manuscript accepted 9 May 1993.
(Wight 1976). In Colorado, N, P, K fertilization improved botanical composition and yield on poor condition range (Currie 1976). Some researchers believe that fertilization can be a valuable tool for range improvement when plant and soil responses are known and applied on a range site basis (Goetz 1969). Graves and McMurphy (1969) concluded that Oklahoma range containing low quality vegetation should not be fertilized. There have been reports that fertilization has resulted in undesirable shifts in botanical composition (Houston and Hyder 1975, Owensby and Smith 1979, Pettit and Deering 1974, Pettit and Fagan 1974, Rauzi 1978, and Wilson et al. 1966).

In Florida, White (1977) reported a $250 \%$ increase in bluestem (Andropogon spp.) forage resulting from N, $\mathrm{P}$, and $\mathrm{K}$ fertilization of pine plantations. Lewis (1970) applied raw-rock phosphate to Florida range with and without chopping and concluded that $\mathbf{P}$ fertilization was a valuable treatment because of its favorable influence on chemical and botanical composition, palatability, and forage yield. Based on these 2 studies it seems that fertilization may have positive effects on creeping bluestem range. The purpose of this research was to determine if $\mathrm{N}, \mathrm{P}$, or $\mathrm{K}$ or their combination would result in greater tiller density, yield, and quality of creeping bluestem.

\section{Materials and Methods}

Experimental Sites, Design, and Treatments

Research was conducted on 2 experimental sites at the University of Florida's Ona Agricultural Research and Education Center in south central Florida $\left(27^{\circ} 25^{\prime} \mathrm{N}, 81^{\circ} 55^{\prime} \mathrm{W}\right)$. The 1988 site was a Pomona fine sand (sandy, siliceous, hyperthermic Ultic Haplquod) with an average organic matter $(O M)$ content $(0$ to $15 \mathrm{~cm}$ depth) of $34 \mathrm{~g} \mathrm{~kg}^{-1}$ and $\mathrm{pH}$ 4.4. The 1989 site was an Ona fine sand (sandy, siliceous, hyperthermic Typic Haplaquod) with an OM content of $52 \mathrm{~g} \mathrm{~kg}^{-1}$ and $\mathrm{pH} 4.4$. The 1988 site will be referred to as Experiment $A$, and this site was fertilized in 1988,1989 , and 1990 , and vegetation was sampled in 1988 and 1990. The 1989 site, Experiment B, was a repeat of Experiment A, and B was fertilized and sampled only in 1989 because of damage by feral hogs in 1990 . Both experimental sites were selected because of good stands of creeping bluestem and little cover from saw-palmetto.

Experiments were split-plots with 4 levels of $\mathrm{N}(0,40,80,120 \mathrm{~kg}$ $\mathrm{ha}^{-1}$ ) forming whole-plots ( 6 by $6 \mathrm{~m}$ ), which were replicated 4 times. Whole plots were separated by a 6-m alley to avoid lateral movement of N (Dantzman and McCaleb 1969). Whole plots were divided in half and sub-plots were assigned a $2^{2}$ factorial in $P$ and $K$ ( 0 or $25 \mathrm{~kg} \mathrm{ha}^{-1} \mathrm{P}$ or 0 or $100 \mathrm{~kg} \mathrm{ha}^{-1} \mathrm{~K}$ ).

Ammonium nitrate, triple super phosphate, and muriate of potash were applied by hand. For Experiment A this was 15 April 1988, 2 June 1989, and 15 April 1990, and for Experiment B this was 5 May 1989. Fertilization of Experiments A and B was delayed in 1989 because of prolonged drought. 


\section{Yield and Tiller Density}

Within each sub-plot (64), a permanent, 6-m transect was established on 15 April 1988 in Experiment A and 5 May 1989 in Experiment B. A $1-\mathrm{m}^{2}$ quadrat $(6 \mathrm{~m}$ by $0.166 \mathrm{~m})$ made from PVC pipe was laid between the transect markers at the beginning of the growing season on 18 April 1988 for Experiment A and 30 May 1989 for Experiment B. On these initial dates, total tillers of creeping bluestem were counted, but not cut.

In Experiment $A$, the $1-\mathrm{m}^{2}$ quadrat was laid parallel to, but not super-imposed on, the permanent transect on 13 May, 6 June, 7 July, and 4 August 1988 (different place on each date). On 7 September, the final sample date of 1988 , the quadrat was placed again on the permanent (initial) transect. The permanent transects in Experiment $A$ were sampled again for yield and tiller density on 24 September 1990 . In Experiment B, the quadrat was employed on 5 June, 26 June, 24 July, and 23 August 1989 in locations adjacent to the permanent transect. On 24 September, the final sample of 1989 , the quadrat was on the permanent transect. At each of these 5 dates in each year creeping bluestem tiller density and yield were determined. In September, vegetative and reproductive tillers were counted separately. Creeping bluestem was cut at the soil surface, dried ( $60^{\circ}$ for 48 hours), ground, and stored for $N, P$, and $K$ analyses.

On each sample date in Experiment A (1988 only), soil within the quadrat was sampled (upper 0 to $15 \mathrm{~cm}$ ) and was analyzed for $P$ (Mehlich I) and $\mathrm{K}$ at the University of Florida's Soil Testing Laboratory (Hanlon and DeVore 1989). Samples were frozen until they were analyzed for $\mathrm{NH}_{4}{ }^{+}$and $\mathrm{NO}_{3}{ }^{-}$. This involved $1 \mathrm{~N} \mathrm{KCl}$ extraction (Hanlon and DeVore 1989). The spodic horizon was sampled for P concentration on May 1991.

Tissue from each sample date in Experiments A and B was analyzed for N, P, and $K$ concentrations. A representative sub-set (154 out 697) was analyzed for N (Gallaher et al. 1975, Hambleton 1977 ), and $N$ was predicted (standard error of calibration $=0.30, R^{2}$ $=0.98$ ) in the remainder of the samples using near-infrared reflectance spectroscopy (Norris et al. 1976). Tissue was ashed at $500^{\circ} \mathrm{C}$ for 6 hours, and nutrients were extracted using $0.3 \mathrm{~m} \mathrm{HCl}$. Solutions were analyzed for $\mathrm{K}$ using an atomic absorption spectrophotometer and for P using a colorimetric method (Murphy and Riley 1962).

\section{Data Analyses}

Data were analyzed using general linear models procedure. Since it was believed that initial tiller number would have an effect on yield, this variable, obtained at the initial tiller counts of Exper- iments $A$ and $B$, was used as a covariate in yield analyses. Yield, tiller density, and tissue mineral content data from Experiments $A$ and B were analyzed as a split-split plot with years (sites) as the whole plot treatment. When there was no interaction with year, data are presented as average over sites. Values for $R^{2}$ were calculated after removing those sources of variation not associated with the regressor variable. In order to provide sufficient decimal places for higher order coefficients and reduce equation size, the independent variables ( $\mathrm{N}$ rate or days) in equations for predicting $\mathrm{g} \mathrm{kg}^{-1}$ $\mathrm{N}$ in tissue are divided by 10 .

\section{Results and Discussion}

Rainfall amount and distribution were similar to the 45-year average for May to September 1988 (Kalmbacher and McCloud 1989) compared to this period in 1989 (Kalmbacher and Whitty 1990). In 1988, only May was below $(-12 \mathrm{~mm})$ the 45 -year average for that month, while all other months were above average rainfall, especially July $(+63 \mathrm{~mm})$ and August $(+112 \mathrm{~mm})$, causing saturated soils. In 1989, which was the driest year in 46 years at Ona, May to September were $-189 \mathrm{~mm}$ below average. May to September 1990 were $-73 \mathrm{~mm}$ below the 47 -year average rainfall.

\section{Effects of N Fertilizer on Yield and Tiller Density}

There were no interactions of $\mathbf{N}$ fertilizer and year in spite of rainfall differences between years. Increasing $\mathbf{N}$ fertilizer increased dry matter yield linearly within each sample date of Experiments $\mathbf{A}$ and B (Table 1, Fig. 1a). Although linear within sample dates, over sample dates $\mathrm{N}$ fertilizer responses were quadratic because yield increases within a $\mathbf{N}$ level were greater at each successive date. Whereas, $1.2 \mathrm{~kg} \mathrm{ha}^{-1}$ of dry matter resulted from each additional $\mathrm{kg}$ $\mathrm{ha}^{-1}$ of $\mathrm{N}$ at 31 days after fertilization, at 55 days $2.5 \mathrm{~kg} \mathrm{ha}^{-1}$ of dry matter resulted, and at 83 days, $7.3 \mathrm{~kg} \mathrm{ha}^{-1}$ of dry matter resulted from each $\mathrm{kg} \mathrm{ha}^{-1}$ of $\mathrm{N}$, etc.

The growth curve for unfertilized creeping bluestem, represented by: $\mathrm{kg} \mathrm{ha}^{-1}=248-0.643 \mathrm{D}+0.053 \mathrm{D}^{2}$, where $\mathrm{D}$ is days since fertilization (Table 1), is a reliable prediction of yield upon which to compare the effect of the addition of $\mathrm{N}$ fertilizer. Yields of unfertilized bluestem in this study were similar to yields of unburned, unfertilized creeping bluestem cut throughout the growing season in an earlier study (Kalmbacher et al. 1985). In this (and earlier) research with unburned, unfertilized creeping bluestem, there was very little reproductive growth when no $\mathrm{N}$ was applied, which will be discussed and related to yield later.

Total tiller density increased linearly with $\mathbf{N}$ fertilizer within each sample date for both Experiments $A$ and $B$, and there were no

Table 1. Equations for creeping bluestem dry matter yield $\left(\mathrm{kg} \mathrm{ha}^{-1}\right)$ and tiller density (no. $\mathrm{m}^{-2}$ ) illustrated in Fig. 1.

\begin{tabular}{|c|c|c|c|c|c|c|c|c|c|}
\hline \multirow[b]{3}{*}{ Equations at: } & \multicolumn{4}{|c|}{ Yield } & \multicolumn{5}{|c|}{ Tiller density } \\
\hline & \multicolumn{3}{|c|}{ Coefficient } & \multirow[b]{2}{*}{$\mathbf{R}^{2}$} & \multicolumn{4}{|c|}{ Coefficient } & \multirow[b]{2}{*}{$\mathbf{R}^{2}$} \\
\hline & Intercept & Linear & Quadratic & & Intercept & Linear & Quadratic & Cubic & \\
\hline \multicolumn{10}{|l|}{ Days $†$} \\
\hline 31 & 319 & 1.23 & & 0.18 & 124 & 0.29 & & & 0.93 \\
\hline 55 & 390 & 2.50 & & 0.22 & 127 & 0.48 & & & 0.14 \\
\hline 83 & 706 & 7.30 & & 0.33 & 118 & 0.65 & & & 0.24 \\
\hline 112 & 987 & 15.88 & & 0.36 & 93 & 0.47 & & & 0.17 \\
\hline $145 \ddagger(1988)$ & 1151 & 39.85 & & 0.57 & 133 & 0.45 & & & 0.24 \\
\hline $145 \ddagger(1989)$ & 1827 & 11.85 & & 0.37 & & & & & \\
\hline \multicolumn{10}{|l|}{$\mathbf{N}$ levels } \\
\hline 0 & 248 & -0.64 & 0.053 & 0.01 & 54 & 3.56 & -0.052 & 0.00021 & 0.008 \\
\hline 40 & 138 & 4.39 & 0.086 & 0.07 & 8 & 6.48 & -0.088 & 0.00035 & 0.014 \\
\hline 80 & 341 & -5.01 & 0.208 & 0.19 & -35 & 9.04 & -0.119 & 0.00046 & 0.022 \\
\hline 120 & 253 & -2.29 & 0.209 & 0.23 & 8 & 7.10 & -0.086 & 0.00031 & 0.012 \\
\hline
\end{tabular}

+Independent variable is rate $\left(\mathrm{kg} \mathrm{ha}^{-1}\right)$. This calculates yield or tiller density over $\mathrm{N}$ levels within a sample date.

$\ddagger$ Yield depended on year at 145 day.

\$Independent variable is days since fertilization. This calculates yield or tiller density over dates within an $\mathrm{N}$ level as shown in Fig. 1 . 
(a) Yield

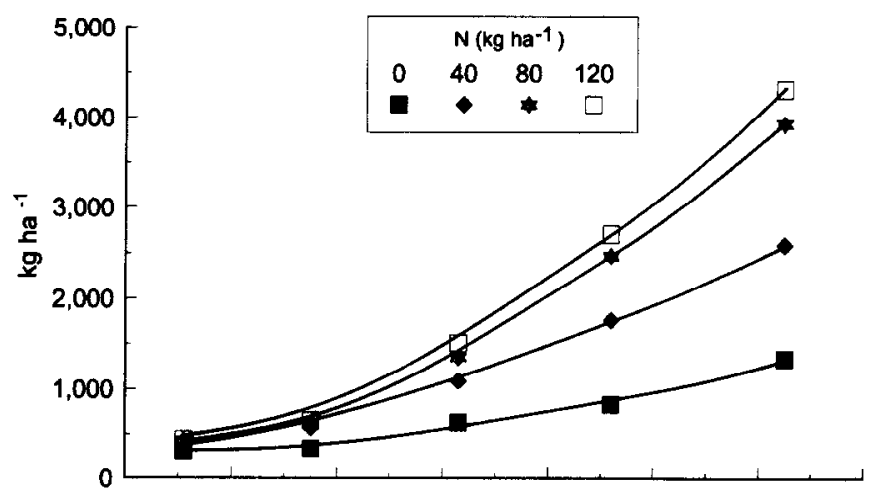

(b) Tiller density

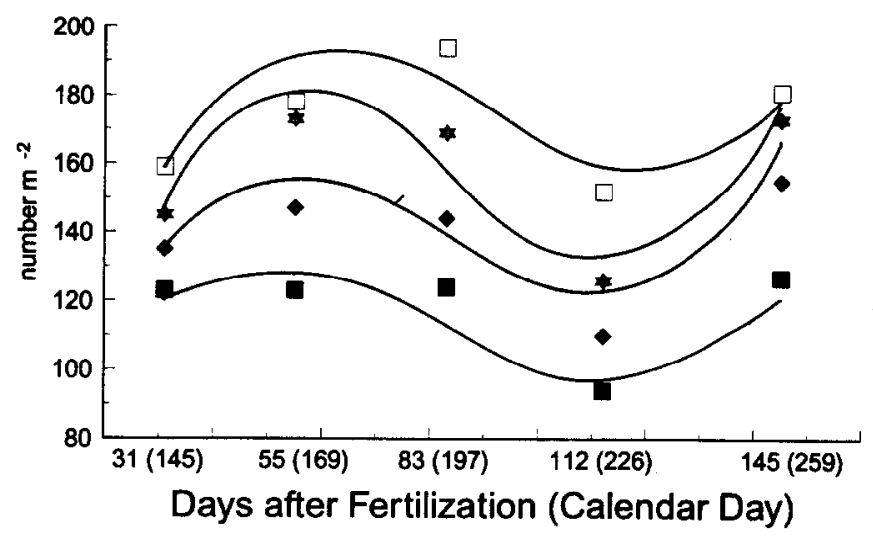

Fig. 1. Effect of N-fertilization on average dry matter yield and tiller density of creeping bluestem in Experiments $A$ (1988) and B (1989). Data are prediction curves and least-square means. Equations are in Table 1. Ona, Fla.

year $\times N$ fertilizer interactions (Table 1, Fig. 1b). Although linear within sample date, over sample dates $\mathrm{N}$ fertilizer responses were cubic. Tiller density increased from 12 to 19 to $26 \mathrm{~m}^{-2}$ for each $40 \mathrm{~kg}$ $\mathrm{ha}^{-1}$ increase in $\mathrm{N}$ between 31,55 , and 83 days after fertilization, respectively. At 112 days after fertilization, $40 \mathrm{~kg} \mathrm{ha}^{-1}$ increments of $\mathrm{N}$ fertilizer resulted in incremental increases of 19 tillers $\mathrm{m}^{-2}$. Each $\mathbf{N}$ level followed a different cubic response over time. Such a cubic pattern for total tiller density is biologically real and has been reported earlier for creeping bluestem (Kalmbacher et al. 1985). There is probably a depression in tiller density due to rainsaturated soil and high temperatures in August (calendar day 226), followed by an increase in density when conditions improve in the fall.

Increases in $\mathrm{N}$ fertilizer resulted in a quadratic increase (no. $\mathrm{m}^{-2}=$ $-3+2.08 \mathrm{~N}-0.0094 \mathrm{~N}^{2}\left[\mathrm{~N}\right.$ is kg ha$\left.\left.{ }^{-1}\right]\right)$ in reproductive tiller density in 1988 and a linear increase (no. $\mathrm{m}^{-2}=30+0.292 \mathrm{~N}$ ) in 1989 (Data not shown). Increases in reproductive tiller density were largely responsible for sharp increases in yield at calendar day 226 and 259 (Fig. 1a). Creeping bluestem begins culm elongation in August, so greater reproductive tiller density as a result of $\mathbf{N}$ fertilization results in greater yield. Experiment A had a large quadratic increase in reproductive tiller density, going from 0 to 110 tillers $\mathrm{m}^{-2}$. Experiment $\mathrm{B}(1989)$ had a linear response, going from about 25 to 60 tillers $\mathrm{m}^{-2}$. This difference between years in response of reproductive tillers was responsible for the interaction (year $\times N$ ) for yield at $\mathbf{1 4 5}$ days after fertilization (Table 1).
From a cattle production standpoint, the increase in yield as a result of additions of $\mathrm{N}$ fertilizer is not desirable because of the large amounts of reproductive growth. Since Florida range is utilized primarily from September to March, forage quality is already low during this period (Long et al. 1986b). Culms (nodes and internodes) and inflorescences makeup about 54 and $21 \%$, respectively, of the unfertilized creeping bluestem dry matter at anthesis, and they contain about $10 \mathrm{~g} \mathrm{~kg}^{-1}$ crude protein and $250 \mathrm{~g}$ $\mathrm{ha}^{-1}$ in vitro organic matter digestibility (IVOMD) (Kalmbacher 1983). Even $80 \mathrm{~kg} \mathrm{ha}^{-1}$ of $\mathrm{N}$, which resulted in about $4,000 \mathrm{~kg} \mathrm{ha}^{-1}$ of dry matter and about 90 reproductive tillers $\mathrm{m}^{-2}$, would not be beneficial because of the relatively low total yield and poor quality. For perspective, a Florida rancher could apply about $70 \mathrm{~kg} \mathrm{ha}^{-1}$ of $\mathrm{N}$ to bahiagrass (Paspalum notatum Flugge) in March and get about $10,000 \mathrm{~kg} \mathrm{ha}^{-1}$ of forage at an average $100 \mathrm{~g} \mathrm{~kg}^{-1}$ crude protein and $540 \mathrm{~g} \mathrm{~kg}^{-1}$ IVOMD over the following 9 months (Summer et al. 1991).

Following 3 annual fertilizer applications, yield of creeping bluestem in Experiment A on 24 September 1990 followed a negative quadratic response $\left(\mathrm{kg} \mathrm{ha}^{-1}=520+16.4 \mathrm{~N}-0.14 \mathrm{~N}^{2}[\mathrm{~N}\right.$ is kg $\mathrm{ha}^{-1}$ ) to $\mathrm{N}$ fertilizer with yield increasing up to $80 \mathrm{~kg} \mathrm{ha}^{-1}$ of applied $\mathrm{N}$, then declining at $120 \mathrm{~kg} \mathrm{ha}^{-1}$ (Data not shown). Yields were only a fraction of what they had been 2 years earlier (Fig. 1a). Note that $0 \mathrm{~N}$ treatment was lower in yield in 1990 compared to 1988 , which may be due to 2 consecutive years of lower than average rainfall. Instead of positive linear relationships as found during the first year (Table 1), all $\mathrm{N}$ levels followed a negative response (no. $\mathrm{m}^{-2}=$ $88-0.45 \mathrm{~N}$ ) for total tiller density in 1990. There was a loss of 1 tiller $\mathrm{m}^{-2}$ for every $2.2 \mathrm{~kg} \mathrm{ha}^{-1}$ of $\mathrm{N}$ applied.

Creeping bluestem was compared to 4 native grasses grown with and without N, P, and $K$ fertilization at the SCS plant material center in Arcadia, Fla. After 3 years of treatment, Roush and Yarlett (1973) described a "weakness in general vigor of creeping bluestem grown under fertilization" that was not explainable when contrasted with unfertilized plants grown in the same row.

We have recently found (unpublished data) survival of creeping bluestem plants from better seed-producing lines was very poor when they were grown on N-P-K fertilized sites. (Kalmbacher et al. 1991). There was abundant reproductive growth, which was desirable for our purposes of seed evaluation, but there was little tillering, which is essential to the following year's growth.

Creeping bluestem generally produces little reproductive growth if not grazed or burned. Yarlett and Roush (1970) reported 1 reproductive to 5 vegetative tillers. White and Terry (1979) found fire stimulated flowering in creeping bluestem the first growing season after burning, and grazing during the first growing season resulted in a decline in tiller density. Our experiments were on range grazed October to March, rather than in the growing season. Additionally, cows grazed the experimental areas only lightly in winter so there was no removal of apical meristems and consequent reduction in tiller density.

\section{Tissue and Soil $\mathbf{N}$}

Tissue $\mathbf{N}$ concentration in creeping bluestem depended on $\mathbf{N}$ fertilizer, sample date, and year (Table 2, Fig. 2). Tissue $N$ concentration declined over sample dates in both years at rates that depended on year and $\mathbf{N}$ fertilizer. Note that the independent variables ( $\mathrm{N}$ rate and days) must be divided by 10 before substituting in all equations in Table 2 . In 1989, $\mathrm{N}$ concentration in fertilized grass was slightly higher than that of unfertilized grass at 5 June (Fig. 2b, 31 days after fertilization) because of the absence of rain. Nitrogen concentration in fertilized grass increased between 5 June and 26 June ( 52 days post) as rain moved $\mathrm{N}$ into the root zone. After 26 June 1989, tissue $N$ concentration in all treatments declined at about the same rate. 
Table 2. Equations for creeping bluestem tissue N-concentrations illustrated in Fig. 2.

\begin{tabular}{|c|c|c|c|c|c|c|}
\hline \multirow{2}{*}{$\begin{array}{l}\text { Equation } \\
\text { for } \mathrm{N} \text { at: }\end{array}$} & \multicolumn{5}{|c|}{ Coefficient } & \multirow[b]{2}{*}{$\mathbf{R}^{2}$} \\
\hline & Intercept & Linear & Quadrat & Cubic & Quartic & \\
\hline \multirow{2}{*}{\multicolumn{7}{|c|}{1988}} \\
\hline & & & & & & \\
\hline 0 & 11.1 & 1.108 & -0.043 & & & 0.91 \\
\hline 26 & 9.3 & 0.366 & & & & 0.76 \\
\hline 55 & 7.5 & -0.036 & 0.019 & & & 0.61 \\
\hline 83 & 6.3 & -0.278 & 0.023 & & & 0.19 \\
\hline 117 & 5.7 & -0.414 & 0.031 & & & 0.49 \\
\hline \multicolumn{7}{|l|}{$\mathrm{N}$ level $\ddagger$} \\
\hline 0 & 11.2 & -0.818 & 0.029 & & & 0.92 \\
\hline 40 & 14.6 & -1744 & 0.078 & & & 0.94 \\
\hline 80 & 17.4 & -2.041 & 0.077 & & & 0.96 \\
\hline 120 & 18.2 & -2.017 & 0.076 & & & 0.96 \\
\hline \multicolumn{7}{|c|}{1989} \\
\hline \multicolumn{7}{|l|}{ Days } \\
\hline 0 & 10.2 & 0.236 & & & & 0.54 \\
\hline 21 & 11.8 & 0.938 & -0.048 & & & 0.75 \\
\hline 49 & 10.4 & 0.204 & & & & 0.50 \\
\hline 79 & 8.1 & 0.125 & & & & 0.23 \\
\hline 111 & 7.2 & -0.543 & 0.108 & -0.005 & & 0.13 \\
\hline \multicolumn{7}{|l|}{$\mathbf{N}$ level } \\
\hline 0 & 10.1 & 1.468 & -0.384 & 0.021 & & 0.76 \\
\hline 40 & 11.4 & 4.317 & -1.656 & 0.195 & -0.0075 & 0.92 \\
\hline 80 & 12.5 & 4.963 & -1.985 & 0.242 & -0.0096 & 0.94 \\
\hline 120 & 12.8 & 3.999 & -1.465 & 0.161 & -0.0059 & 0.94 \\
\hline
\end{tabular}

Independent variable is $\mathrm{N}$ rate divided by 10 . This calculates $\mathrm{N}$ content $\left(\mathrm{g} \mathrm{kg}^{-1}\right)$ over $\mathrm{N}$ level within harvest date.

$\ddagger$ Independent variable is dates since first sampled divided by 10 . This calculates $\mathrm{N}$ content over time within an $\mathrm{N}$ level.

There are 2 reasons for the decline in $\mathrm{N}$ concentration in tissue over time. The first is the dilution of $\mathrm{N}$ as plant dry matter accumulated. Early in summer, when the plant is leafy and yields are low, $\mathrm{N}$ is more concentrated in tissue than after August when much dry matter has accumulated, especially as a result of reproductive growth. The dilution of $\mathbf{N}$ was probably responsible for higher $\mathbf{N}$ concentration in unfertilized bluestem compared to fertilized bluestem at fall dates, when for instance at 7 September 1989 unfertilized bluestem contained $5.7 \mathrm{~g} \mathrm{~kg}^{-1}$ of $\mathrm{N}$ while bluestem receiving $120 \mathrm{~kg} \mathrm{ha}^{-1}$ of $\mathrm{N}$ contained $5.3 \mathrm{~g} \mathrm{~kg}^{-1}$. Similar differences occurred at 111 and 145 days after fertilization in 1988 and at 100 and 142 days in 1989.

A second reason for the decline in tissue $\mathbf{N}$ concentration over time was the diminishing supply of $\mathbf{N}$ from the soil as the season progressed (Fig. 3). On 29 April 1988, 14 days after application of $\mathrm{N}$ (and after $7 \mathrm{~mm}$ rain), soil $\mathrm{NH}_{4}{ }^{+}$concentration increased linearly over fertilizer treatments from 8 to $42 \mathrm{mg} \mathrm{kg}^{-1}$. Concentration of $\mathrm{NO}_{3}{ }^{-}$in soil increased linearly from 5 to $19 \mathrm{mg} \mathrm{kg}^{-1}$ at this date. Rainfall was more typical of south Florida in 1988, that is, the rainy season began in late May and continued throughout September with periodic flooding of soils in July and August. Concentrations of $\mathrm{NH}_{4}{ }^{+}$and $\mathrm{NO}_{\mathrm{c}}{ }^{-}$in soil declined steadily after 29 April such that there were no differences in $\mathrm{NH}_{4}{ }^{+}$or $\mathrm{NO}_{3}{ }^{-}$concentrations between $\mathrm{N}$-fertilizer treatments after June 8.

\section{Effects of $P$ and $K$ Fertilizer}

Application of $P$ had no effect $(P>0.05)$ on yield or tiller density in creeping bluestem. Applied $P$ increased $(P<0.05)$ concentration of $P$ in the upper 0 to $15 \mathrm{~cm}$ of soil sampled at all 5 dates in 1988 . Averaged over all 1988 dates, soil $P(0$ to $15 \mathrm{~cm})$ was $10 \mathrm{mg} \mathrm{kg}^{-1}$ when no $P$ was applied and $13 \mathrm{mg} \mathrm{kg}^{-1}$ when $25 \mathrm{~kg} \mathrm{ha}^{-1} \mathrm{P}$ was applied.

In spite of low amounts of Mehlich I extractable $P$ in the upper 0

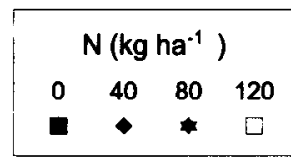

(a) 1988

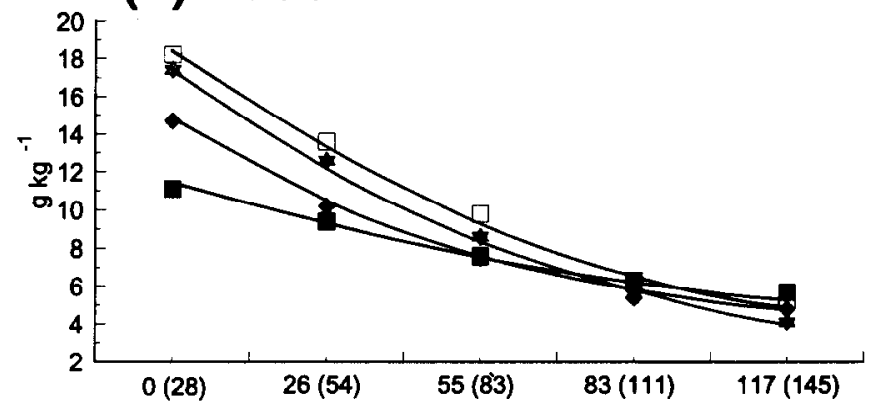

(b) 1989

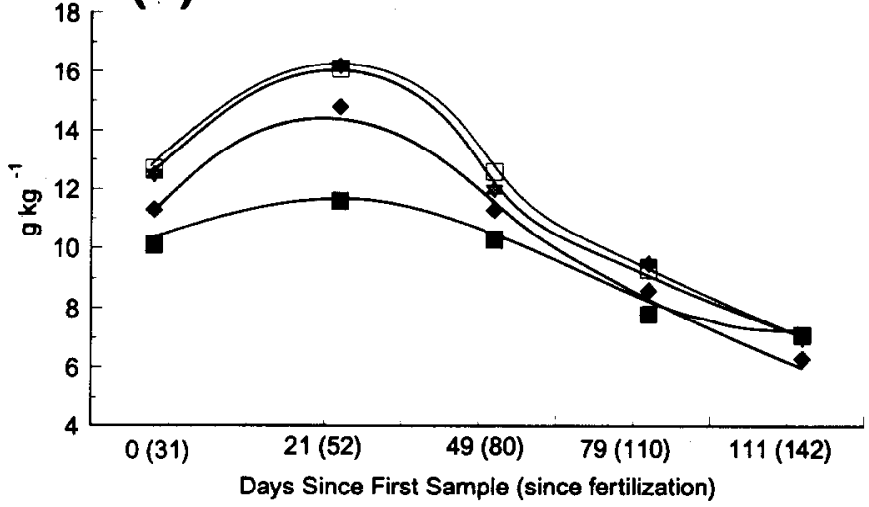

Fig. 2. Nitrogen (DM basis) of whole-plant samples of creeping bluestem depended on $\mathrm{N}$-fertilizer rate and year. These data are prediction curves and least-square means for Experiment $A$ (1988) and B (1989). Equations are in Table 2.

to $15 \mathrm{~cm}$ of soil, many grasses in Florida do not yield more with additions of $P$ fertilizer. For example, yield of bahiagrass did not increase after addition of up to $30 \mathrm{~kg} \mathrm{ha}^{-1}$ of $P$ following initial application at establishment (McCaleb et al. 1966). Apparently, there is little demand for $P$ in pasture where recycling occurs, but more importantly, the spodic horizon of Florida soils contains large amounts of inherent $P$, and fertilizer $P$ accumulates in the spodic horizon (Dantzman and McCaleb 1969). The spodic horizon in Experiment $A$, which was at an average depth of $0.45 \mathrm{~m}$ below the soil surface, contained an average $10 \mathrm{mg} \mathrm{kg}^{-1}$ of $P$ (range of 4 to $32 \mathrm{mg} \mathrm{kg}^{-1}$ ), which was about the same as that in the 0 to $15-\mathrm{cm}$ layer. Our levels of extractable $P$ in the spodic horizon were not high compared to that reported by Dantzman and McCaleb (1969), who reported a range of 45 to $3,200 \mathrm{mg} \mathrm{kg}^{-1}$ at the Ona AREC.

Concentration of $\mathbf{P}$ in tissue was increased by application of $\mathbf{P}$ only on 13 May and 7 September 1988 in Experiment A, but no response was observed at individual dates in Experiment $B$. When averaged over all Experiment $\mathbf{A}$ or $\mathbf{B}$ dates, $\mathbf{P}$ content in tissue depended on $\mathrm{N}$. When $25 \mathrm{~kg} \mathrm{ha}^{-1}$ of $P$ was applied, $P$ concentration in tissue is described: $\mathrm{g} \mathrm{kg}^{-1}=1.46-0.00026 \mathrm{~N}$ (Experiment $\mathrm{A}$ ) or $\mathrm{g}$ $\mathrm{kg}^{-1}=1.12-0.00018 \mathrm{~N}$ (Experiment $\mathrm{B}$ ), where $\mathrm{N}$ is kg ha ${ }^{-1}$. When no $\mathbf{P}$ was applied, there was a cubic response over $\mathbf{N}$ rates in Experiment $A\left(P\right.$ in $\mathrm{g} \mathrm{kg}^{-1}=1.32-0.0097 \mathrm{~N}+0.00023 \mathrm{~N}^{2}-$ $\left.0.0000014 \mathrm{~N}^{3}\right)$ and no significant regression in Experiment $B$.

Application of $\mathrm{K}$ increased $(P<0.05)$ creeping bluestem yield in 

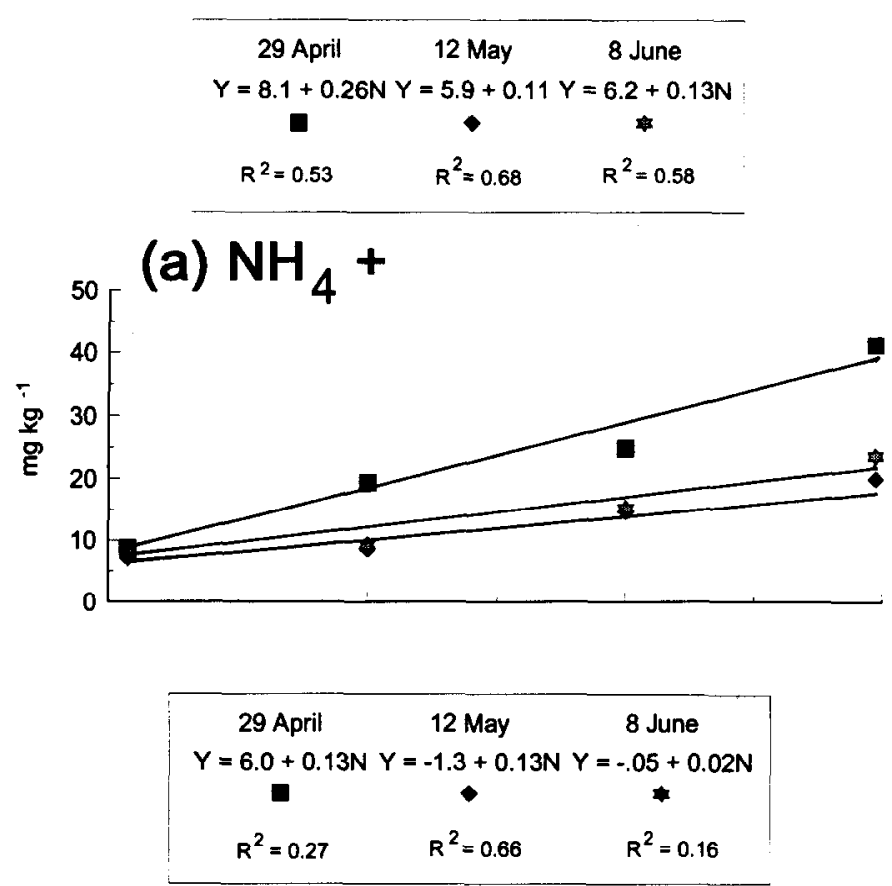

(b) $\mathrm{NO}_{3}-$

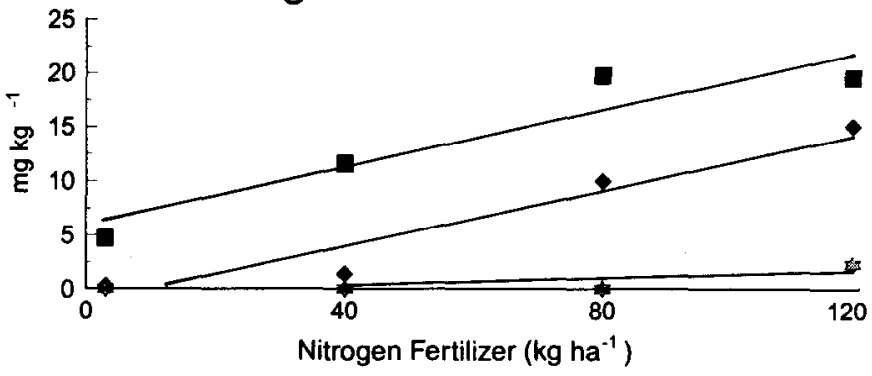

Fig. 3. Effect of $\mathrm{N}$-fertilization on concentration of $\mathrm{NO}_{3}^{-}$and $\mathrm{NH}_{4}^{+}$in soil (dry basis) from Experiment A (1988). Data are prediction curves and least-square means. Ona, Fla.

Experiments $A$ and $B$ (no interaction with year) at August (1,720 and $2,160 \mathrm{~kg} \mathrm{ha}^{-1}$ with 0 and $100 \mathrm{~kg} \mathrm{ha}^{-1} \mathrm{~K}$, respectively), and September $\left(2,320\right.$ and $3,760 \mathrm{~kg} \mathrm{ha}^{-1}$ with 0 and $100 \mathrm{~kg} \mathrm{ha}^{-1} \mathrm{~K}$, respectively) sample dates. Apparently, the increase in yield at these times was due to an increase in density of reproductive tillers when $\mathrm{K}$ fertilizer was applied. When $100 \mathrm{~kg} \mathrm{ha}^{-1}$ of $\mathrm{K}$ was applied, reproductive tiller density increased $(P<0.01)$ from 47 to 70 tillers $\mathrm{m}^{-2}$ and total tiller density increased from 142 to 176 tillers $\mathrm{m}^{-2}$. Vegetative tiller density was not different $(P>0.05)$ between $\mathrm{K}$ levels and averaged 99 tillers $\mathrm{m}^{-2}$.

Extractable $K$ in soil was increased at every Experiment $A$ sample date with the addition of $100 \mathrm{~kg} \mathrm{ha}^{-1}$ of $\mathrm{K}$, and analysis over sample dates within year indicated soil $\mathbf{K}$ concentration depended on level of $\mathrm{N}$ applied. When no $\mathrm{K}$ was applied, soil $\mathrm{K}$ concentration was the same over levels of $\mathrm{N}$, but when $\mathrm{N}$ was applied to plots also receiving $100 \mathrm{~kg} \mathrm{ha}^{-1}$ of $\mathrm{K}$, soil $\mathrm{K}$ concentration declined: $\mathrm{mg} \mathrm{kg}^{-1}=$ $46-0.052 \mathrm{~N}$, where $\mathrm{N}$ is $\mathrm{kg} \mathrm{ha}^{-1}$. This indicates that the growth response of creeping bluestem resulted in greater demand for $K$ and more extraction of $\mathrm{K}$ from the soil in the presence of $\mathrm{N}$.

Tissue $\mathrm{K}$ concentration in Experiment $\mathrm{A}$ was increased at every sample date by application of $K$, but $K$ concentration was not affected on any sample date in Experiment $B$. The effect of $K$ on this response in 1988 was inconsistent because tissue $\mathrm{K}$ increased on 13 May and 7 July 1988, then decreased at August and Sep- tember sampling dates. The decrease at later sample dates may be due to dilution of tissue $K$ because of the increase in tiller density, hence yield, as a result of $K$ application.

When analyzed over all 1988 sample dates, applying $100 \mathrm{~kg} \mathrm{ha}^{-1}$ of $\mathrm{K}$ increased 1988 average tissue $\mathrm{K}$ concentation when $25 \mathrm{~kg} \mathrm{ha}^{-1}$ of $P$ was also applied $\left(5.9 \mathrm{~g} \mathrm{~kg}^{-1}\right.$ for $+K+P$ vs $5.1 \mathrm{~g} \mathrm{~kg}^{-1}$ for $\left.-K+P\right)$, but applying $K$ without $P$ did not increase tissue $K\left(5.7 \mathrm{~g} \mathrm{~kg}^{-1}\right.$ for $-K-P$ vs $5.6 \mathrm{~g} \mathrm{~kg}^{-1}$ for $\left.+K-P\right)$. Without $K, P$ decreased tissue $K(5.7$ $\mathrm{g} \mathrm{kg}^{-1}$ for $-\mathrm{K}-\mathrm{P}$ vs 5.1 for $-\mathrm{K}+\mathrm{P}$ ). With $\mathrm{K}$, applying $\mathrm{P}$ resulted in no difference in tissue $\mathrm{K}\left(5.6 \mathrm{~g} \mathrm{~kg}^{-1}\right.$ for $+\mathrm{K}-\mathrm{P}$ vs $5.9 \mathrm{~g} \mathrm{~kg}^{-1}$ for $\left.+\mathrm{K}+\mathrm{P}\right)$.

\section{Conclusions}

Addition of $\mathrm{N}$ up to $120 \mathrm{~kg} \mathrm{ha}^{-1}$ increased creeping bluestem dry matter yield linearly at each of 5 sample dates on 2 sites (years). Over sample dates, yield was quadratic, depending on $\mathbf{N}$ rate. Tiller density increased linearly to $\mathrm{N}$ rates within a sample date and quadratically over sample dates. Reproductive tiller density was greatly increased by $\mathrm{N}$ fertilization. Addition of $25 \mathrm{~kg} \mathrm{ha}^{-1}$ of $\mathrm{P}$ had no effect on yield or tiller density. Applying $100 \mathrm{~kg} \mathrm{ha}^{-1}$ of $\mathrm{K}$ increased tiller density and yield on both sites (years).

Considering the large increase in reproductive tiller density of creeping bluestem as a result of $\mathrm{N}$ and $\mathrm{K}$ fertilization, the increase in yield for cattle forage is undesirable because of the poor forage quality associated with reproductive growth if forage is to be grazed in fall and winter. Yield and tiller density in creeping bluestem annually receiving $\mathrm{N}$ fertilization treatments for 3 years were reduced quadratically and linearly, respectively, as a result of increasing $\mathbf{N}$ rates. Fertilization of creeping bluestem is not a recommended practice when bluestem is grazed in fall and winter.

\section{Literature Cited}

Currie,P.0. 1976. Recovery of ponderosa pine-bunchgrass ranges through grazing and herbicide or fertilizer treatments. J. Range Manage. 29:444-448.

Dantzman, C.L., and J.E. McCaleb. 1969. Movement of some fertilizer elements in flatwoods soils. Soil Crop Sci. Soc. Fla. Proc. 29:123-130.

Gallaher, R.N., C.O. Weldon, and J.G. Futral. 1975. An aluminum digester for plant and soil analysis. Soil Sci. Soc. Amer. Proc. 39:803-806.

Goetz, H. 1969. Composition and yields of native grassland sites fertilized at different rates of nitrogen. J. Range Manage. 22:384-390.

Goetz, H. 1975. Effect of site and fertilization on protein content of native grasses. J. Range Manage. 28:380-385.

Graves, J.E., and W.E. MeMurphy. 1969. Burning and fertilization for range improvement in central Oklahoma. J. Range Manage. 22:165-168.

Hambleton, L.G. 1977. Semiautomated method for simultaneous determination of phosphorus, calcium and crude protein in animal feeds. J. Assoc. Off. Agr. Chem. 60:845-852.

Hanlon, E.A., and J.M. DeVore. 1989. IFAS extension soil testing laboratory chemical procedures and training manual. Florida Agr. Exp. Sta. Circ. 812.

Houston, W.R., and D.N. Hyder. 1975. Ecological effects and fate of $\mathbf{N}$ following massive $\mathbf{N}$ fertilization of mixed-grass plains. J. Range Manage. 28:56-60.

Kalmbacher, R.S. 1983. Distribution of dry matter and chemical constituents in plant parts of four Florida native grasses. J. Range Manage. 36:298-301.

Kalmbacher, R.S., W.F. Brown, F.G. Martin, and S.W. West. 1991. Potential of creeping bluestem for improvement of grazing on Florida range. Crop Sci. 31:373-379.

Kalmbacher, R.S., K.R. Long, M.K. Johnson, and F.G. Martin. 1984. Botanical composition of the diets of cattle grazing south Florida rangelands. J. Range Manage. 37:334-340.

Kalmbacher, R.S., F.G. Martin, and J.0. Andrade. 1981. Yield and quality of creeping bluestem as affected by time of cutting. J. Range Manage. $34: 471-474$

Kalmbacher, R.S., F.G. Martin, and W.D. Pitman. 1986. Effect of grazing time and intensity on creeping bluestem. J. Range Manage. 39:223-227.

Kalmbacher, R.S., F.G. Martin, W.S. Terry, D. Hunter, and L.D. White. 1985. Effects of clipping on burned and unburned creeping bluestem. J. Range Manage. 38:531-535. 
Kalmbacher, R.S., and D.E. McCloud. 1989. Ona climatological report, 1988. Ona AREC Research Report. RC-1989-1.

Kalmbacher, R.S., and E.G. Whitty. 1990. Ona climatological report. Ona AREC Research Report. RC-1990-1.

Lewis, C.E. 1970. Responses to chopping and rock phosphate on south Florida ranges. J. Range Manage. 23:276-282.

Long, K.R., R.S. Kalmbacher, and F.G. Martin. 1986a. Diet quality of steers grazing three range sites in south Florida. J. Range Manage. 39:389-392.

Long, K.R., R.S. Kalmbacher, and F.G. Martin. 1986b. Effect of season of grazing and regrazing on diet quality of burned Florida range. J. Range Manage. 39:518-521.

McCaleb, J.E., C.L. Dantzman, and E.M. Hodges. 1966. Response of pangolagrass and Pensacola bahiagrass to different amounts of phosphorus and potassium. Soil Crop Sci. Soc. Florida. Proc. 26:248-256.

Murphy, J., and J.P. Riley. 1962. A modified single solution method for the determination of phosphate in natural waters. Anal. Chem. Acta. 27: 31-36.

Norris, K.H., R.F. Barnes, J.E. Moore, and J.S. Shenk. 1976. Predicting forage quality by infrared reflectance spectroscopy. J. Animal Sci. 43:889-897.

Owensby, C.E., and E.F. Smith. 1979. Fertilizing and burning Flint Hills bluestem. J. Range Manage. 32:254-258.

Pettit, R.D., and D.W. Deering. 1974. Yield and protein content of sandyland range forages as affected by three nitrogen fertilizers. J. Range Manage. 27:211-213.
Pettit, R.D., and R.E. Fagan. 1974. Influence of nitrogen on irrigated buffalograss yield and protein content. J. Range Manage. 27:473-476.

Rauzi, F. 1978. High rates of nitrogen change composition of shortgrass rangeland in southeastern Wyoming. J. Range Manage. 31:366-370.

Roush, R.D., and L.L. Yarlett. 1973. Creeping bluestem compared with four other native range grasses. J. Range Manage. 26:19-21.

Sumner, S., W. Wade, J. Selph, J. Southwell, V. Hogue, E. Jennings, P. Miller, and T. Seawright. 1991. Fertilization of established bahiagrass pasture in Florida. Florida Agr. Exp. Sta. Circ. 916.

White, L.D. 1977. Forage production in a five-year-old fertilized slash pine plantation. J. Range Manage. 30:131-134.

White, L.D., and W.S. Terry. 1979. Creeping bluestem response to prescribed burning and grazing in south Florida. J. Range Manage. 32:369-371.

Wight, J.R. 1976. Range fertilization in the Northern Great Plains. J. Range Manage. 39:180-185.

Wilson, A.M., G.A. Harris, and D.H. Gates. 1966. Fertilization of mixed cheatgrass-bluebunch wheatgrass stands. J. Range Manage. 19:134-137.

Yarlett, L.L. 1965. Control of saw palmetto and recovery of native grasses. J. Range Manage. 18:344-345.

Yarlett, L.L., and R.D. Roush. 1970. Creeping bluestem [Andropogon stolonifer (Nash.) Hitchc.]. J. Range Manage. 23:117-122.

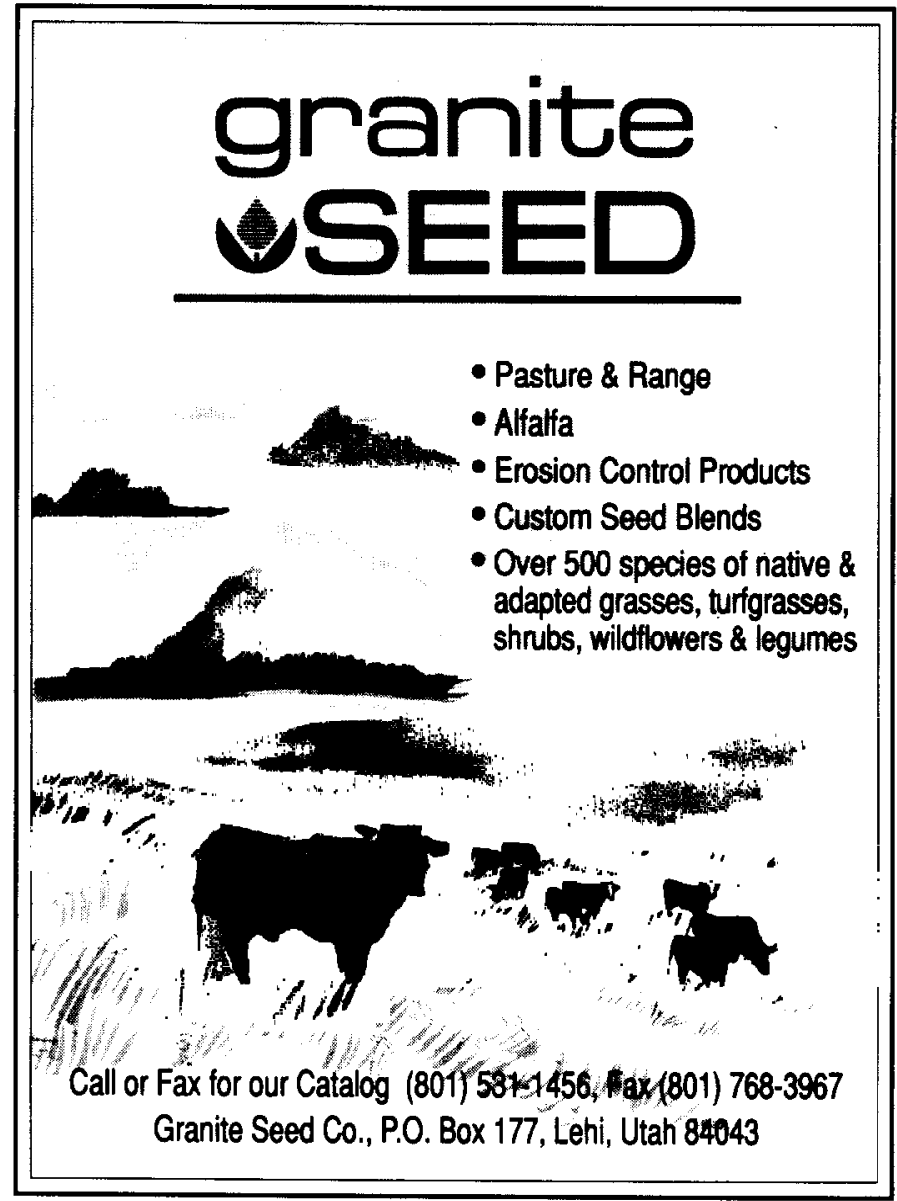

